XXIII. Descriptions of two Species of Antelope from India. By Major-General Thomas Hardwicke, F.R.S. and L.S. \&.c.

Read February 18, and June 17, 1823.

\title{
A NTILOPE.
}

Subgenus III. Cervicapre. Desmar. Encyclop.

**** Cornibus recurvatis.

Antilope Goral.

A. CORNiBus brevibus approximatis recurvis subulatis basi annulatis ultra medium lævibus, corpore supra colore murino canescente subtus pallidiore, gula albente, cauda brevi attenuata subfloccosa, oculis sinubus lacrymalibus.

$$
\text { TAB, XIV. }
$$

This small Antelope is a native of the Himalayah range and the mountains of the Nepaul frontier; and by the natives of those regions it is called Goral.

Its size is about that of a common goat, of extraordinary agility, leaping to a great extent, and with great sureness of footing ; very timid.

Head very conical, rather compressed, and tapering suddenly from the eyes to the snout, very wide across the cheeks, and narrowing towards the forehead. Horns black, short $\left(4 \frac{1}{2}\right.$ inches), subulate, approximating at the base, gently bending backwards, and slightly diverging towards their apex, smooth, 


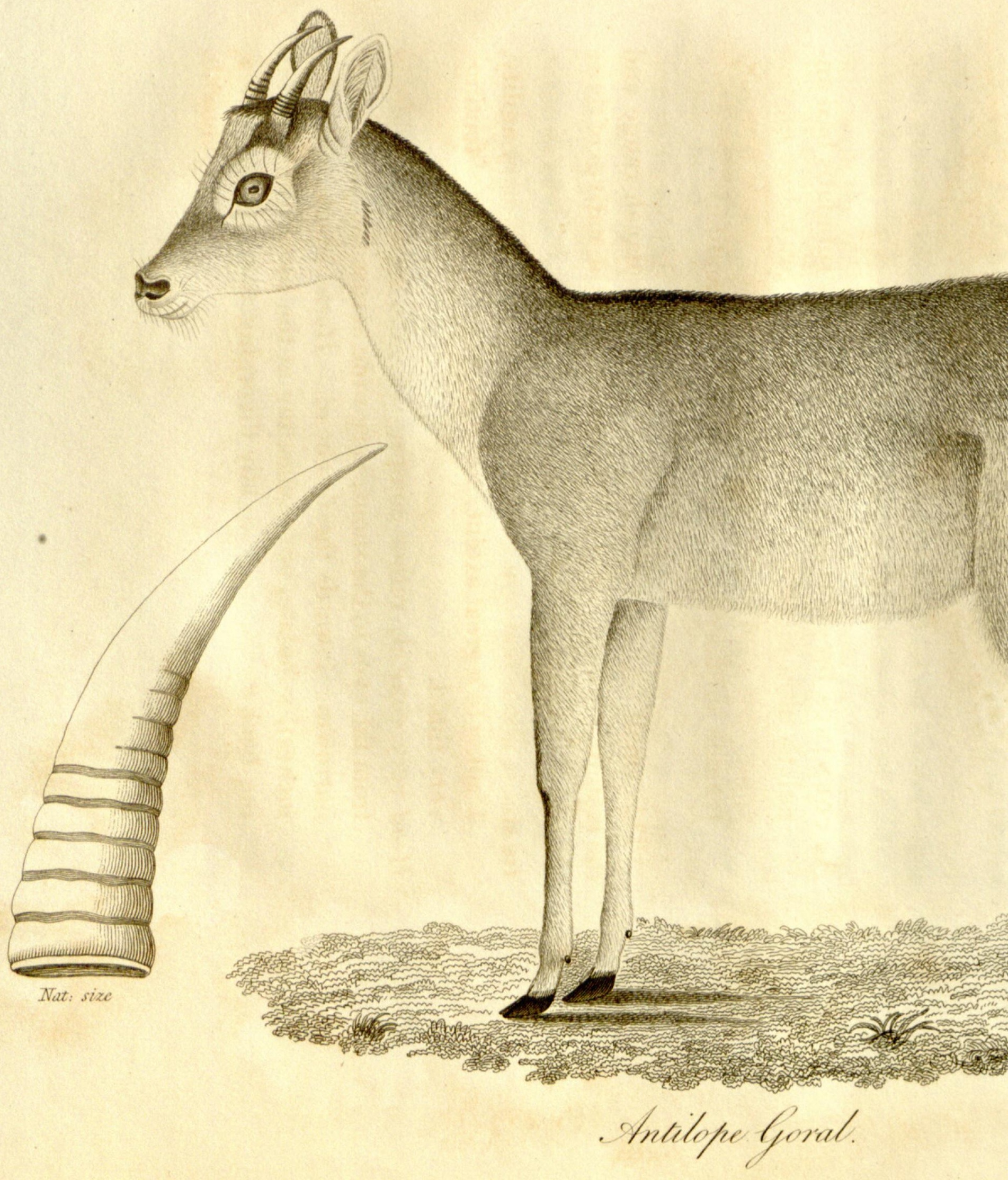


Major-Gen. HA R D IC K e on two Species of Antelope, \&c. 519 smooth, excepting their base, which is marked with five or six gentle annular ridges, occupying about one-third of the whole length, gradually disappearing upwards. Eyes rather large, of a dark brown, surrounded with a circle of whitish hairs, and long, slender, black eyelashes. Ears large, five inches in length, ovate, erect; hair within white. Neck proportionably long. Body roundish; the back a little arched, which has the appearance of being higher at the rump, but is not so ; it is the natural position of the animal, which seems as if always prepared to take a leap: from the rump to the tail much sloped. Legs slender, well formed; hoofs black. Tail slender, tapering, about four inches long.

The general colour is a grey mouse-colour (but almost white about the lower part of the neck and throat), and darker; with the hair longer along the upper part of the neck and back, inclining to ferruginous about the legs.

The length of this animal from the top of the Feet. Inches.

head to the root of the tail is

$3 \quad 1$

And in height from the foot to the back . . 20

Length of the neck . . . . . . . . . . . 0 . $9 \frac{1}{2}$

Length of the head . . . . . . . . 0 . 5

Girth of the body . . . . . . . . . 22

Length of the fore legs from the elbow . . . 12

Circumference of the fore leg above the knee $\quad \begin{array}{llll}0 & 6\end{array}$

Ditto of hind leg above the joint . . $0 \quad 6$

Ditto below the knee of both legs . . 03

The foregoing description is of the male. The female differs but little; has no horns, but in their place appear two prominent tubercles, covered with a tuft of dark-brown hairs. 
Of these animals, a male and female were presented by the Court of Kathmandre to the Resident, the Honourable Edward Gardner; and the male is living in the collection of animals in the Governor-general's menagerie at Barrackpore.

Its flesh is, in the estimation of those who have eaten of it, considered delicate venison.

I find, on conversing with an intelligent native from the Valley of Kathmandre, that the name of this animal is pronounced with a single $o$, and open; as in over, go-cart, \&c.

It is considered by the natives of Nepaul as the most active of the Antelope species. It is seen in numerous herds, but is rarely taken, excepting by stratagem. If pursued, they disperse, and fly to precipices and places to which no dogs can follow them.

The subject from which the drawing and description was taken gave me proof of its agility in a space of about ten feet square, inclosed by stakes of eight or nine feet in height. These the animal attempted to spring over, and at every leap so nearly effected its purpose as to appear to a person looking on in imminent danger of being staked.

\section{**** Cornibus quatuor.}

\section{Antilope Chickara.}

A. cornibus quatuor, anterioribus erectis cylindricis brevibus abrupte acuminatis basi subapproximatis, posterioribus subelongatis subulatis lævigatis rectis paululum divergentibus.

$$
\text { TAB. XV. and XVI. }
$$

This species of Antelope seems hitherto to have escaped any particular description of the naturalist; and this circumstance is the more remarkable, as the animal is not scarce in India. 


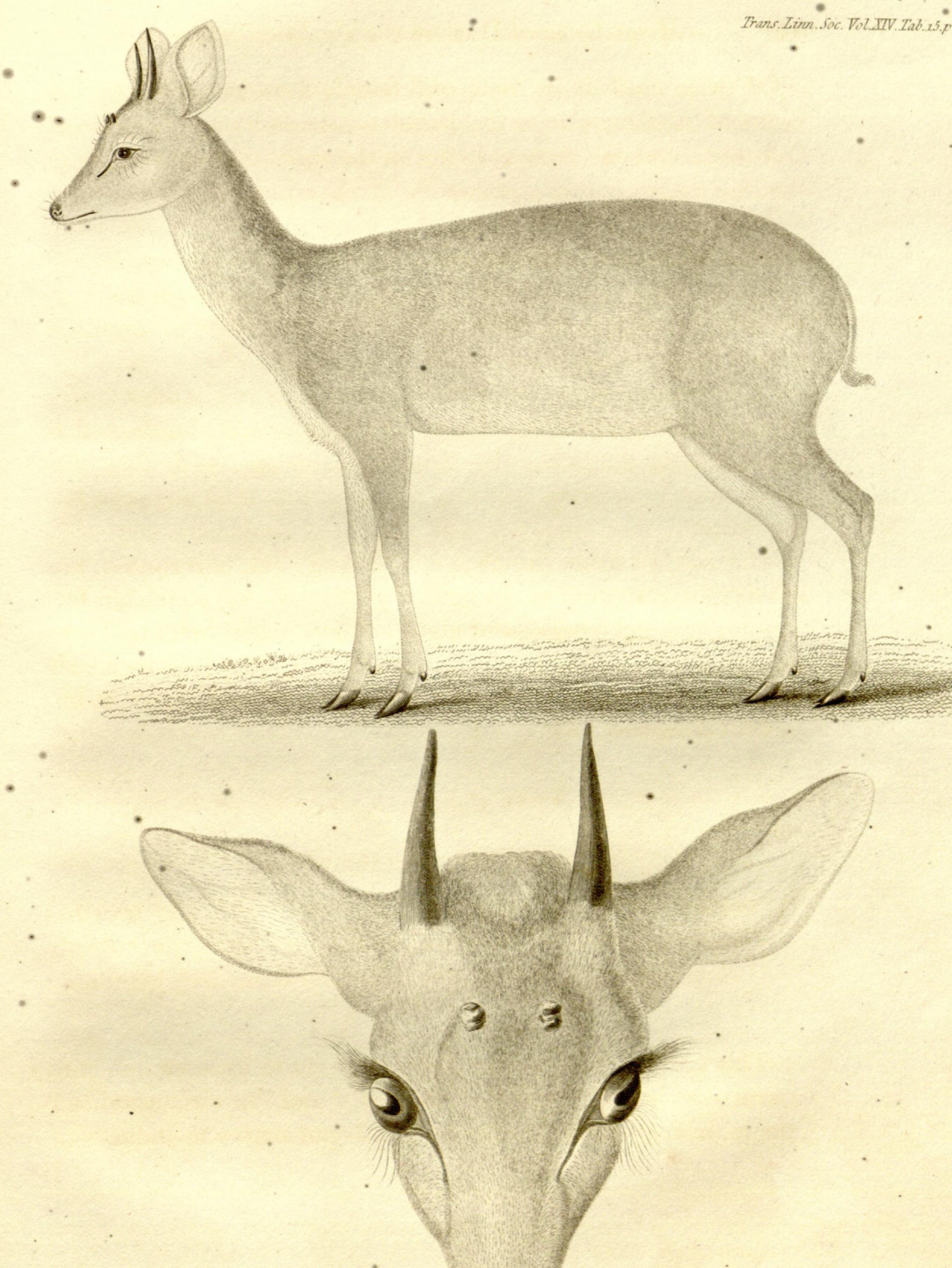


It inhabits the forests and hilly tracts along the western provinces of Bengal, Behar, and Orissa, and is known by the name of Chikara.

It is an extremely wild and agile creature, and only to be tamed when taken young.

In size this species is something less than the Harnessed Antelope (A. Scripta); it is in height, from the foot to the top of the shoulder, $20 \frac{1}{2}$ inches; and in length, from the nose to the root of the tail, 33 inches, or 2 feet 9 inches; and the tail is $5 \frac{1}{2}$ inches more.

The superior or common horns are black, subulate, rounded, without annulations, smooth, and erect, slightly inclined forward, and a little diverging; their length 3 inches; space between them, at the base, 1 inch $\frac{8}{10}$ ths, and at their tips 2 inches $\frac{4}{10}$ ths. The greatest thickness at the base is 2 inches in circumference, and gradually tapering to a point of $\frac{1}{10}$ th of an inch diameter. In front of the common horns ( 1 inch $\frac{4}{10}$ ths) in the middle of the forehead, and between the eyes, rises a very short pair of spurious horns, erect, stumpy, smooth, cylindrical, $\frac{3}{4}$ ths of an inch in length, $1 \frac{1}{2}$ inch in circumference at the base, and suddenly tapering to a point; they are apart at the base $\frac{3}{4}$ ths of an inch, and at their tips 1 inch $\frac{2}{10}$ ths.

Head in length $7 \frac{1}{2}$ inches, and its greatest circumference across the cheeks and behind the spurious horns 13 inches. Ears mostly erect, ovate; the greatest breadth about $2 \frac{1}{4}$ inches, and length $4 \frac{3}{4}$ inches. Nose naked and black, the margin. of the lips black. Eyes large, with strong bristly black eyelashes. Limbs delicately made, the shanks of the fore legs being $2 \frac{1}{2}$ inches in circumference, and those of the hind 3 inches; the proper and spurious hoofs are black; the greatest circumference of the body 29 inches. 
The general colour of the animal is an uniform bright bay on all the upper parts ; and below, i.e. the chin, the under line of the neck, the abdomen, the inner sides of the thighs, and under the tail, are inclined to white, more or less mixed with sandy hairs.

Teeth in the lower jaw eight in front, the two middle ones being greatly larger than the six lateral teeth, and spread out; their inner margins rounded, and not touching, and their internal surfaces hollowed like a spoon: in the hinder part of the jaw, on each side, are six strong grinders, with pointed surfaces, and a like number in the upper jaw similarly constructed.

This is the description of a male subject, TAB. XV. The female, $T_{\text {A }}$. XVI. differs only in having no horns, and being of lighter colours. This distinction of colour is found to be a permanent character ; it at least remained so for the four years I kept a pair in my possession, and within which period they bred: two young ones were produced at the same birth, one a male, the other a female; and the distinction of colour as above was conspicuous at that early stage, and continued.

The male in the rutting season becomes exceedingly wild and mischievous, and, although partly domesticated, continues dangerously so, running at every animal within its reach, whether deer, goat, or man. Even the feeder could only approach him on the verge of the circle to which the rope he was tied with allowed him to reach.

The prepared head, which will accompany this paper, belonged to the subject under description. The spurious horns will be found blunted, the animal having worn off the points by his struggles occasionally to emancipate himself. 


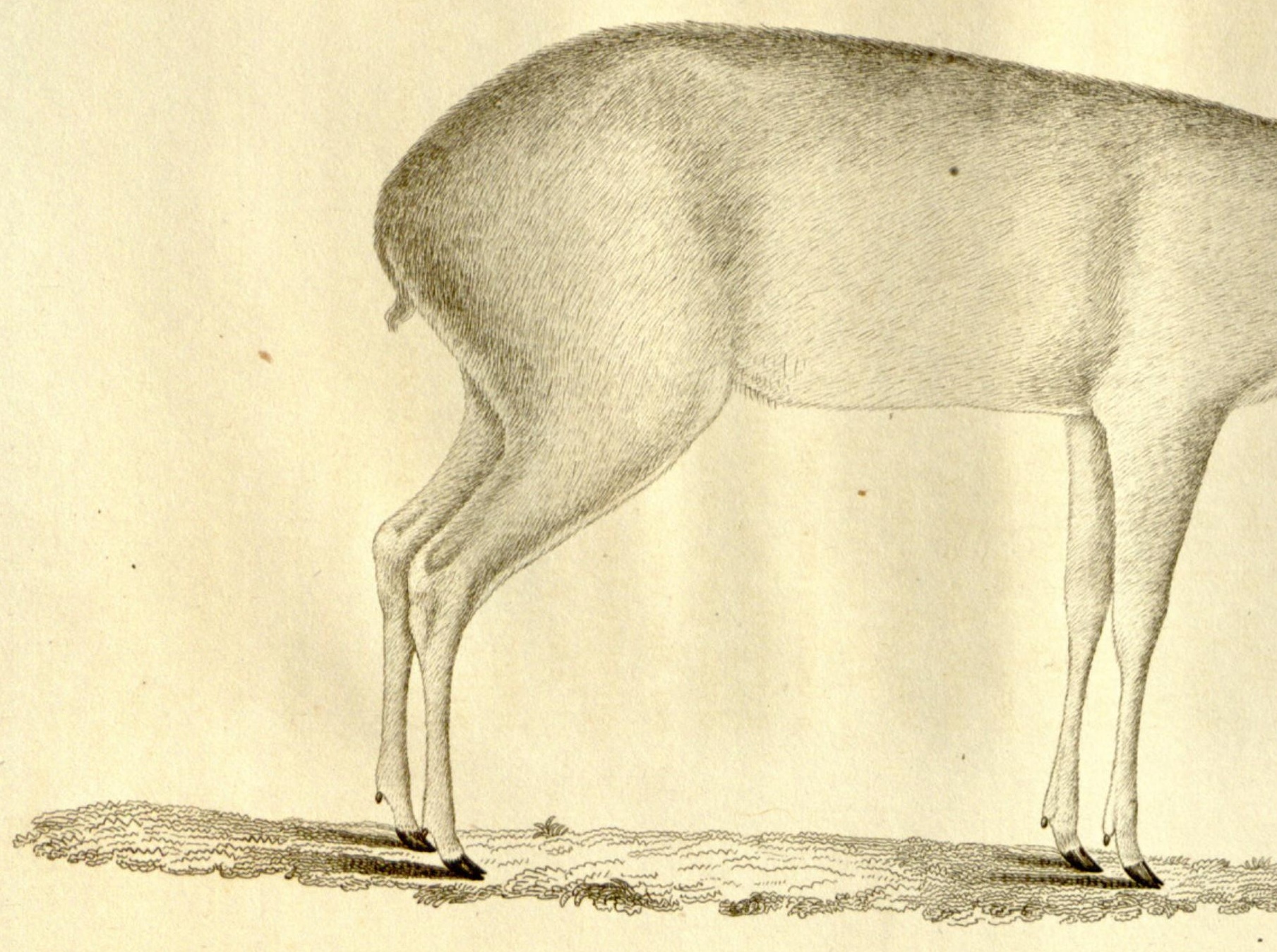

Stulitope Chickaras fom. 
Note. - It is to be regretted that, owing to the accidental delay which has attended the printing of the foregoing paper, the respectable authors of the Histoire Naturelle des Mammifères have, in the 44th livraison of that very splendid work, published an imperfect description of the Chickara, or, as it is there printed, Tchicara, which is undoubtedly the Antilope Chickara above described.

In the work referred to it is stated that the largest or posterior horns are "grossièrement annelées à leur base ;" whereas, by reference to the head in the Museum of this Society, it appears that Major-general Hardwicke is correct in stating that those horns are entirely smooth. The French description, and the figure which accompanies it, are stated to have been received from M. Devaucel; and there is reason to believe that both were taken from a drawing which that naturalist saw in Majorgeneral Hardwicke's possession, and of which he solicited a copy when he visited the Major-general at the artillery cantonments at Dum-Dum in 1822. At that time M. Devaucel also saw both the male and the female alive in the possession of General Hardwicke; and the French description might afterwards have been partly made up from memory; for it is rather remarkable that M. Devaucel should have asked for a copy of the General's drawing, if he had actually the living animals in his own possession, as asserted in his communication to the authors of the French work. It is also remarkable, if M. Devaucel had such a good opportunity of giving a full description of the species, that the French authors should have occasion to regret the insufficiency of the notes which were transmitted to them with the drawing. M. Devaucel notices the name by which this animal is known in Nepaul ; but in all General Hardwicke's inquiries, which were more extensive than M. Devaucel's could have been, he did not discover that the animal was found in Nepaul. 


\section{$2 \mathrm{BHL}$ Biodiversity Heritage Library}

Hardwicke, Thomas. 1825. "Descriptions of two Species of Antelope from India." Transactions of the Linnean Society of London 14, 518-524.

https://doi.org/10.1111/j.1095-8339.1823.tb00099.x.

View This Item Online: https://www.biodiversitylibrary.org/item/13693

DOI: https://doi.org/10.1111/j.1095-8339.1823.tb00099.x

Permalink: https://www.biodiversitylibrary.org/partpdf/32060

\section{Holding Institution}

Missouri Botanical Garden, Peter H. Raven Library

\section{Sponsored by}

Missouri Botanical Garden

\section{Copyright \& Reuse}

Copyright Status: Public domain. The BHL considers that this work is no longer under copyright protection.

This document was created from content at the Biodiversity Heritage Library, the world's largest open access digital library for biodiversity literature and archives. Visit BHL at https://www.biodiversitylibrary.org. 